\title{
Effect of intensive endurance training on rat brain and hepatic 8-oxoguanine DNA glycosylase and 8-hydroxy-2'-deoxyguanosine levels
}

\author{
Mohammad Esmaiel Afzalpour ${ }^{1}$, Hossein TaheriChadorneshin ${ }^{2}$, Seyed-Hosein Abtahi-Eivary ${ }^{3 *}$, Ehsan Afroozi-Gerow ${ }^{1}$ \\ ${ }^{1}$ Department of Sport Sciences, University of Birjand, Birjand, Iran. \\ ${ }^{2}$ Department of Sport Sciences, University of Bojnord, Bojnord, Iran. \\ ${ }^{3}$ Department of Clinical Biochemistry, Gonabad University of Medical Sciences, Gonabad, Iran.
}

\section{ARTICLE INFO \\ Article history: \\ Received on: 14/09/2016 \\ Revised on: 24/10/2016 \\ Accepted on: 16/11/2016 \\ Available online: 28/12/2016}

\section{Key words:}

Endurance training,

8-oxoguanine DNA

glycosylase, 8-hydroxy-2'-

deoxyguanosine, Liver,

Brain.

\begin{abstract}
The purpose of this study was to investigate the effect of intensive endurance training on 8 -oxoguanine DNA glycosylase (OGG1) and 8-hydroxy-2'-deoxyguanosine (8-OHdG) levels in liver and brain of rats. 16 adult and male albino wistar rats were randomly divided into sedentary control and endurance exercise training groups. Animals ran on treadmill for 6 weeks, 6 days a week, at a speed of $10 \mathrm{~m} / \mathrm{min}$ ( 85 percent of maximal oxygen consumption). The content of OGG1 and 8-OHdG were measured using sandwich ELISA assay. Data analyzed using Student's T-test at $\mathrm{P} \leq 0.05$ level. Our results showed that intensive endurance training has no significant effect on 8-OHdG contents in liver $\left(\mathrm{t}_{14}=1.09, \mathrm{p}=0.29\right)$ and brain $\left(\mathrm{t}_{14}=0.93, \mathrm{p}=0.36\right)$ of rats. However, contents of OGG1 in liver $\left(\mathrm{t}_{14}=5.84, \mathrm{p}=0.001\right)$ and brain $\left(\mathrm{t}_{14}=4.09, \mathrm{p}=0.001\right)$ of rats significant increases following intensive endurance training. Finally, there were no significantly differences between changes in contents of 8-OHdG $\left(\mathrm{t}_{14}=0.44, \mathrm{p}=0.66\right)$ and OGG1 $\left(\mathrm{t}_{14}=1.72, \mathrm{p}=0.10\right)$ in liver and brain of rats following endurance training. Intensive endurance training maintains $8-\mathrm{OHdG}$ genomic damage in baseline level in liver and brain of rats by increasing contents of OGG1.
\end{abstract}

\section{INTRODUCTION}

Regular exercise training has many health benefits and act as protective approach against diseases (Ogonovszky et al., 2005a, 2005b). Paradoxically, it is also obvious that free radical induced by intense exercise training can result in oxidative damage to cellular constituents (Radak et al., 2006, 2008, Nikolaidis et al., 2009). Free radical attacks to protein and lipids and yield carbonyl protein and malondialdehyde, respectively (Radak et al., 2006, 2008, Nikolaidis et al., 2009). In addition, free radical generated by contracting skeletal muscles penetrates into the mitochondria and the nucleus which result in oxidative damage to genomic constituents (Ogonovszky et al., 2005a, 2005b). In fact, the production of 8-hydroxy-2'-deoxyguanosine

\footnotetext{
* Corresponding Author

Seyed-Hosein Abtahi-Eivary, Department of Clinical Biochemistry, Gonabad University of Medical Sciences, Gonabad, Iran.

E-mail: abtahi.h@gmu.ac.ir
}

(8-OHdG) and subsequently cell apoptosis occurs following free radical attack (Ogonovszky et al., 2005a, Radak et al., 2007, 2008). Due to its lower redox potential compare to other nucleic acid bases, guanine is prone to undergo further oxidation upon exposure to hydroxyl radicals. Therefore, 8-hydroxy-2'deoxyguanosine $(8-\mathrm{OHdG})$ is frequently generated oxidative base lesion (Radak et al., 2003). Transversion of G:C to T:A and mutation occurs if unrepaired $8-\mathrm{OHdG}$ is not repair. 8-OHdG level increases during many diseases such as cancer, atherosclerosis, diabetes and Alzheimer's disease (Ogonovszky et al., 2005a, Radak et al., 2007, 2008). Cells are equipped with DNA repair system to reduce the effects of these oxidative DNA damages. 8oxoguanine DNA glycosylase (OGG1) recognizes and cleaves of oxidized guanine from DNA (Radak et al., 2007, 2011). Maximum oxygen consumption ( $\left.\mathrm{VO}_{2} \max \right)$ (Loft et al., 1994), body mass index (BMI) (Kasai et al., 2001) and exercise training (Ogonovszky et al., 2005a, Koltai et al., 2011) influence on OGG1 and 8-OHdG levels. 
Although, exercise training at low intensity had no significant effect on 8-OhdG and acetylated OGG1 levels, but overtraining increased 8-OhdG and OGG1 levels in liver tissue of rats (Ogonovszky et al., 2005a). In contrast, a reduction in 8OHdG levels in liver of old rats has been reported following 8 weeks running on treadmill (Nakamoto et al., 2007). Furthermore, both of running on treadmill (Radak et al., 2007, Nakamoto et al., 2007) and swimming (Radak et al., 2009) with moderate intensity increase OGG1 activity in the red type of skeletal muscle (Radak et al., 2007) and liver (Nakamoto et al., 2007) and subcellular compartments i.e nucleus and mitochondria (Radak et al., 2009). Increases in OGG1 activity is higher in slow twich than fast twich muscle fiber following exercise training with moderate intensity (Radak et al., 2007). Also, marathon running alters the DNA base excision repair in human skeletal muscle (Radak et al., 2003). In contrast, these increases return to baseline level after detraining (Radak et al., 2009).

In the context of other indicators of oxidative damage, Fauzi and colleague has been reported an increases in malondialdehyde and superoxide dismutase (Fauzi et al., 207). Also, Kayatekin and co-workers have been shown that 6 weeks intensive interval training increases glutathione peroxidase levels, while has no effect on superoxide dismutase (Kayatekin et al., 2002). Moreover, Fisher and co-workers has been demonstrated increase in catalase, superoxide dismutase, and glutathione peroxidase level in lymphocytes (Fisher et al., 2010). Due to insufficient information regarding the health effects of intense endurance training on OGG1 and 8-OHdG, the results of present study will give us a new insight about intensity of training. Especially, due to activation of NADPH oxidase (Haram et al., 2009) and xanthine oxidase (Kostaropoulos et al., 2006) more free radical produces during intense training. In addition, liver and brain are considered as redox sensitive organs in body because of large number of mitochondria, ischemia/reperfusion of blood (Cooper et al., 2002, Lamprecht et al., 2004) and large amounts of iron and copper ions (Cooper et al., 2002, Urso et al., 2003). Finally, preserving the structure of DNA is critical for cell metabolism and the correct transmission of information. Collectively, the purpose of this study was to investigate the effect of intensive endurance training on OGG1 and 8-OHdG levels in the liver and brain of rats.

\section{MATERIALS AND METHODS}

\section{Animals}

All animal experiments conformed to the guidelines for the use and care of laboratory animals ("Principles of laboratory animal care", NIH publication No. 86-23. Revised 1996), and the study was approved by the ethics committee of Birjand University of Medical Sciences in Iran. Sixteen adult and male albino wistar (12 weeks of age, weighing $280 \mathrm{~g}$ ) were randomly assigned to two groups of control and intensive endurance training. The animals were kept under controlled conditions with $25 \pm 2^{\circ} \mathrm{C}$ and a 12 -h light/12-h dark cycle. The rats had free access to tap water and food. The animals were accustomed to laboratory conditions for 2 weeks prior to the experiment.

\section{Intensive endurance training}

Animals were familiarized with running on a motordriven treadmill (12-lane) for 5 days, $10 \mathrm{~min} /$ day at a speed of 10 $\mathrm{m} / \mathrm{min}$ (Afzalpour et al., 2015). Intensive endurance training was performed on the basis of overload principle for 6 weeks, 6 sessions per week (Table 1) (Afzalpour et al., 2015). Overload was exerted by increasing the training time. At the beginning and end of intensive endurance training, warm-up and cool-down were performed at $16 \mathrm{~m} / \mathrm{min}$ (corresponds to $68 \% \mathrm{VO}_{2} \mathrm{max}$ ). Besides, intensities of intensive endurance training correspond to $80 \%$ $\mathrm{VO}_{2}$ max. The rats were motivated to run by a mild electrical current on the treadmill $(0.5 \mathrm{~mA}, 1 \mathrm{~Hz})$ (Afzalpour et al., 2015). The rats of the control group were transported daily to the training room, exposed to the same environment as the exercising groups, and placed on the treadmill without running for as long as the exercising groups were on the treadmill (Afzalpour et al., 2015).

Table 1: Intensive endurance trainings protocols.

\begin{tabular}{|c|c|c|}
\hline Week & Day & Intensive endurance training \\
\hline \multirow[t]{6}{*}{ Week 1} & 1 & $20 \mathrm{~min}, 27 \mathrm{~m} / \mathrm{min}$ \\
\hline & 2 & $22 \mathrm{~min}, 27 \mathrm{~m} / \mathrm{min}$ \\
\hline & 3 & $24 \mathrm{~min}, 27 \mathrm{~m} / \mathrm{min}$ \\
\hline & 4 & $26 \mathrm{~min}, 27 \mathrm{~m} / \mathrm{min}$ \\
\hline & 5 & $28 \mathrm{~min}, 27 \mathrm{~m} / \mathrm{min}$ \\
\hline & 6 & $30 \mathrm{~min}, 27 \mathrm{~m} / \mathrm{min}$ \\
\hline \multirow[t]{6}{*}{ Weak 2} & 1 & $32 \mathrm{~min}, 27 \mathrm{~m} / \mathrm{min}$ \\
\hline & 2 & $34 \mathrm{~min}, 27 \mathrm{~m} / \mathrm{min}$ \\
\hline & 3 & $36 \mathrm{~min}, 27 \mathrm{~m} / \mathrm{min}$ \\
\hline & 4 & $38 \mathrm{~min}, 27 \mathrm{~m} / \mathrm{min}$ \\
\hline & 5 & $40 \mathrm{~min}, 27 \mathrm{~m} / \mathrm{min}$ \\
\hline & 6 & $42 \mathrm{~min}, 27 \mathrm{~m} / \mathrm{min}$ \\
\hline \multirow[t]{6}{*}{ Weak 3} & 1 & $44 \mathrm{~min}, 27 \mathrm{~m} / \mathrm{min}$ \\
\hline & 2 & $46 \mathrm{~min}, 27 \mathrm{~m} / \mathrm{min}$ \\
\hline & 3 & $48 \mathrm{~min}, 27 \mathrm{~m} / \mathrm{min}$ \\
\hline & 4 & $50 \mathrm{~min}, 27 \mathrm{~m} / \mathrm{min}$ \\
\hline & 5 & $52 \mathrm{~min}, 27 \mathrm{~m} / \mathrm{min}$ \\
\hline & 6 & $54 \mathrm{~min}, 27 \mathrm{~m} / \mathrm{min}$ \\
\hline \multirow[t]{6}{*}{ Weak 4} & 1 & $56 \mathrm{~min}, 27 \mathrm{~m} / \mathrm{min}$ \\
\hline & 2 & $58 \mathrm{~min}, 27 \mathrm{~m} / \mathrm{min}$ \\
\hline & 3 & $60 \mathrm{~min}, 27 \mathrm{~m} / \mathrm{min}$ \\
\hline & 4 & $60 \mathrm{~min}, 27 \mathrm{~m} / \mathrm{min}$ \\
\hline & 5 & $60 \mathrm{~min}, 27 \mathrm{~m} / \mathrm{min}$ \\
\hline & 6 & $60 \mathrm{~min}, 27 \mathrm{~m} / \mathrm{min}$ \\
\hline Weak 5-6 & $1-12$ & $\begin{array}{l}60 \mathrm{~min}, 27 \mathrm{~m} / \mathrm{min} \text {, } \\
\text { to end of } 6^{\text {th }} \text { week }\end{array}$ \\
\hline
\end{tabular}

Tissue preparation and Biochemical assays

Rats were euthanized under deep anesthesia (Ketamine, 60-80 mg/kg and Xylazine, $8 \mathrm{mg} / \mathrm{kg}$; IP) $48 \mathrm{~h}$ after last exercise session, between 10:00 and 11:00 am. The whole brain and liver rat was removed, washed by normal saline, and finally stored at $80{ }^{\circ} \mathrm{C}$. Brain and liver were smashed into a fine powder by liquid nitrogen (22). Then, $1 \mathrm{ml} 1 \times$ phosphate buffered saline and protease inhibitor cocktail (\#GB-326-1, ProBlock ${ }^{\mathrm{TM}}-50$, Goldbio technology CO, USA) added to the microtubes. Commercially 96well ELISA kits were used to measure the content of OGG1 (\#CSB-EL016313RA, Cusabio Biotech CO., LTD. SinoAmerican) and 8-OHdG levels (\#CSB-E10526r, Cusabio Biotech 
CO., LTD. Sino-American). The sensitivities of OGG1 and 8OHdG were less than $6.25 \mathrm{pg} / \mathrm{ml}$ and $0.078 \mathrm{ng} / \mathrm{ml}$, respectively. The assays were carried out according to the manufacturer's instructions. Contents were expressed in $\mathrm{mg}$ tissue weight.

\section{Statistical analysis}

Data were analyzed by Statistical Package for Social Sciences (SPSS Inc., Chicago, USA) version 16.0 and expressed as mean \pm standatd deviation (SD). After determination of normality BY Shapiro-Wilk's test, the data were statistically analyzed by Student's t-test. Significance level was set at $\mathrm{p}<0.05$.

\section{RESULTS}

Our finding showed that intensive endurance training significantly increase contents of OGG1 in liver $\left(\mathrm{t}_{14}=\mathbf{5} .84\right.$, $\mathrm{p}=0.001)$ and brain $\left(\mathrm{t}_{14}=4.09, \mathrm{p}=0.001\right)$ of rats (Table 2$)$. However, intensive endurance training has no significant effect on $8-\mathrm{OHdG}$ contents in liver $\left(\mathrm{t}_{14}=1.09, \mathrm{p}=0.29\right)$ and brain $\left(\mathrm{t}_{14}=0.93, \mathrm{p}=0.36\right)$ of rats (Table 2). Also, there were no significantly differences between changes in contents of OGG1 $\left(\mathrm{t}_{14}=1.72, \mathrm{p}=0.10\right)$ and 8OHdG $\left(\mathrm{t}_{14}=0.44, \mathrm{p}=0.66\right)$ of rats following intensive endurance training (Table 2).

Table 2: Effect of intense endurance training on OGG1 and 8-OHdG levels in liver and brain.

\begin{tabular}{lcc}
\hline \multirow{2}{*}{ Dependent variables } & Control & $\begin{array}{c}\text { Intensive endurance } \\
\text { training }\end{array}$ \\
\cline { 2 - 3 } & $40.33 \pm 3.69$ & $50 \pm 3.01^{*}$ \\
Liver OGG1 $(\mathrm{pg} / \mathrm{mg}$ tissue $)$ & $11.40 \pm 2.89$ & $17.14 \pm 2.70^{*}$ \\
Brain OGG1 $(\mathrm{pg} / \mathrm{mg}$ tissue) & $0.88 \pm 0.11$ & $0.80 \pm 0.17$ \\
Liver 8-OHdG $(\mathrm{ng} / \mathrm{mg}$ tissue) & $0.29 \pm 0.08$ & $0.25 \pm 0.08$ \\
Brain 8-OHdG $(\mathrm{ng} / \mathrm{mg}$ tissue) & * Indicate significant difference than control $(\mathrm{P}<0.05)$.
\end{tabular}

\section{DISCUSSION}

It has been shown that physical labor, BMI, interindividual variation, nutrient (Kasai et al., 2001) age (Radak et al., 2011), smoking (Park et al., 2011), $\mathrm{VO}_{2} \max$ (Loft et al., 1994), and mental state, especially clinical depression (Forlenza et al., 2006), all affect OGG1 levels. Therefore, animal models were used in the present study to control the variables mentioned. Therefore, observed changes in OGG1 and 8-OHdG are simply due to intensive endurance training. While it have been reported that running (Koltai et al., 2011) and swimming (Ogonovszky et al., 2005b) with low to moderate intensity have no significant influence on OGG1 and 8-OHdG levels in rat's hippocampus, our findings show an increase in OGG1 contents of brain and liver following intensive endurance training. Our findings are supported by a study by Ogonovszky who reported an increase in OGG1 activity and 8-OHdG levels of rat liver following strenuous and overtraining (Ogonovszky et al., 2005a). This increasing is largely attributed to high number of mitochondria, higher metabolism of liver cells, and no significantly changes in SOD, GPX and catalase activity of liver cells following exercise (Ogonovszky et al., 2005a). In contrast, the level of DNA damage and OGG1 activity in brain did not significantly alter with increasing in exercise intensity (Ogonovszky et al., 2005b) due to increasing of antioxidant enzymes activity in different region of brain (Ogonovszky et al., 2005b).

Liver and brain, as two redox sensitive organs, react differently to changes in oxygen supply during exercise; however, adaptive processes related to oxidative challenges are very similar (Cooper et al., 2002, Urso et al., 2003, Lamprecht et al., 2004). Higher levels of iron and copper ions in the brain tissue increase the possibility of Fenton reaction (Cooper et al., 2002, Urso et al., 2003). Furthermore, higher production of ROS in the liver cells is associated to high density of mitochondria (Lamprecht et al., 2004, Cooper et al., 2002).

In this regard, it is reported that $8-\mathrm{OHdG}$ levels in mitochondria of liver is 10 times higher than $8-\mathrm{OHdG}$ levels in nucleus because of close proximity to electron transport chain (Nakamoto et al., 2007). Furthermore, ischemia/blood reperfusion which occurs at the beginning and end of each set of intense exercise training increases the xanthine oxidase enzyme activity and subsequently damage to genomic structures (Lamprecht et al., 2004). However, in our study, HIIT had no significant effect upon the 8 -OHdG levels of brain and liver. Studies have been shown that OGG1 activity increases after 8 weeks of running on treadmill exercise (Nakamoto et al., 2007) and swimming training (Radak et $a l ., 2009)$. In addition, it has been reported that voluntary wheel running increases the activity of antioxidant enzymes in different region of brain (Ogonovszky et al., 2005b, Jolitha et al., 2006). Collectively, no change in $8-\mathrm{OHdG}$ levels in brain and liver following intensive endurance training may be attributed to higher levels of OGG1 activity (Nakamoto et al., 2007, Radak et al., 2009), higher levels of antioxidant enzyme activity (Ogonovszky et al., 2005a, Jolitha et al., 2006) and higher contents of OGG1 as shown in the present study.

Interestingly, our results did not reveal any significant difference in changes of OGG1 and 8-OHdG between brain and liver. This suggests same response of OGG1 and 8-OHdG levels in two mentioned organs following intensive endurance training.

\section{CONCLUSION}

In general, intensive endurance training increases the OGG1 content in liver and brain and it seems that this adjustment is critical in control and modifies the oxidative damage following intensive endurance training.

\section{Financial support and sponsorship: Nil.}

Conflict of Interests: There are no conflicts of interest.

\section{REFRENCESS}

Afzalpour ME, Chadorneshin HT, Foadoddini M, Eivari HA. Comparing interval and continuous exercise training regimens on neurotrophic factors in rat brain. Physiol Behav, 2015; 147: 78-83.

Cooper C, Vollaard NB, Choueiri T, Wilson M. Exercise, free radicals and oxidative stress. Biochem Soc Trans, 2002; 30(2): 280-5.

Fauzi F, Budin SB, Azwan SH, Leong, Yuen K. The effect of 5 -week exercise program on oxidative stress and response to acute 
exercise among sedentary subjects. J Sai Kesih Mala, 2007; 5: 39-52.

Fisher G, Schwartz DD, Quindry J, Barberio MD, Foster EB, Jones $\mathrm{KW}$, et al. Lymphocyte enzymatic antioxidant responses to oxidative stress following high-intensity interval exercise. J Appl Physiol, 2010; 110: 730-737.

Forlenza MJ, Miller GE. Increased serum levels of 8-hydroxy2'-deoxyguanosine in clinical depression. Psychosom Med, 2006; 68(1): 1 7.

Haram PM, Kemi OJ, Lee SJ, Bendheim MØ, Al-Share QY, Waldum HL, Gilligan LJ, Koch LG, Britton SL, Najjar SM, Wisløff U. Aerobic interval training vs. continuous moderate exercise in the metabolic syndrome of rats artificially selected for low aerobic capacity. Cardiovasc Res, 2009; 81(4): 723-32.

Jolitha A, Subramanyam M, Devi SA. Modification by vitamin $\mathrm{E}$ and exercise of oxidative stress in regions of aging rat brain: studies on superoxide dismutase isoenzymes and protein oxidation status. Exp Gerontol, 2006; 41(8): 753-63.

Kasai H, Iwamoto-Tanaka N, Miyamoto T, Kawanami K, Kawanami S, Kido R, Ikeda M. Life style and urinary 8-hydroxydeoxyguanosine, a marker of oxidative DNA damage: effects of exercise, working conditions, meat intake, body mass index, and smoking. Jpn J Cancer Res, 2001; 92(1): 9-15.

Kayatekin B, Gönenç S, Açikgöz O, Uysal N, Dayi A. Effects of sprint exercise on oxidative stress in skeletal muscle and liver. Eur $\mathrm{J}$ of Appl Physiol, 2002; 2: 141-144.

Koltai E, Zhao Z, Lacza Z, Cselenyak A, Vacz G, Nyakas C, Boldogh I, Ichinoseki-Sekine N, Radak Z. Combined exercise and insulinlike growth factor-1 supplementation induces neurogenesis in old rats, but do not attenuate age-associated DNA damage. Rejuvenation Res, 2011; 14(6): 585-96.

Kostaropoulos I, Nikolaidis M, Jamurtas A, Ikonomou G. Comparison of the blood redox status between long-distance and shortdistance runners. Physiol Res, 2006; 55(6): 611.

Lamprecht M, Greilberger J, Oettl K. Analytical aspects of oxidatively modified substances in sports and exercises. Nutrition, 2004; 20(7-8): 728-30.

Loft S, Astrup A, Buemann B, Poulsen HE. Oxidative DNA damage correlates with oxygen consumption in humans. FASEB J, 1994; 8(8): 534-7.

Nakamoto H, Kaneko T, Tahara S, Hayashi E, Naito H, Radak $\mathrm{Z}$, et al. Regular exercise reduces 8-oxodG in the nuclear and mitochondrial DNA and modulates the DNA repair activity in the liver of old rats. Exp Gerontol, 2007; 42(4): 287-95.

Nikolaidis MG, Jamurtas AZ. Blood as a reactive species generator and redox status regulator during exercise. Arch Biochem Biophys, 2009; 490(2): 77-84.

Ogonovszky H, Berkes I, Kumagai S, Kaneko T, Tahara S, Goto S, Radák Z. The effects of moderate-, strenuous-and over-training on oxidative stress markers, DNA repair, and memory, in rat brain. Neurochem Int, 2005b; 46(8): 635-40.
Ogonovszky H, Sasvári M, Dosek A, Berkes I, Kaneko T, Tahara S, Nakamoto H, Goto S, Radák Z. The effects of moderate, strenuous, and overtraining on oxidative stress markers and DNA repair in rat liver. Can J Appl Physiol, 2005a; 30(2): 186-95.

Park K-S, Lee Y. Lymphocyte apoptosis in smokers and nonsmokers following different intensity of exercises and relation with lactate. Int J Exerc Sci, 2011; 4(3): 204-216

Radák Z, Apor P, Pucsok J, Berkes I, Ogonovszky H, Pavlik G, Nakamoto H, Goto S. Marathon running alters the DNA base excision repair in human skeletal muscle. Life Sci, 2003; 72(14): 1627-33.

Radak Z, Atalay M, Jakus J, Boldogh I, Davies K, Goto S. Exercise improves import of 8-oxoguanine DNA glycosylase into the mitochondrial matrix of skeletal muscle and enhances the relative activity. Free Radic Biol Med, 2009; 46(2): 238-43.

Radak Z, Bori Z, Koltai E, Fatouros IG, Jamurtas AZ, Douroudos II, et al. Age-dependent changes in 8-oxoguanine-DNA glycosylase activity are modulated by adaptive responses to physical exercise in human skeletal muscle. Free Radic Biol Med, 2011; 51(2): 417-23.

Radak Z, Chung HY, Goto S. Systemic adaptation to oxidative challenge induced by regular exercise. Free Radical Biology and Medicine. 2008;44(2):153-9.

Radak Z, Kumagai S, Nakamoto H, Goto S. 8-Oxoguanosine and uracil repair of nuclear and mitochondrial DNA in red and white skeletal muscle of exercise-trained old rats. Journal of Applied Physiology. 2007;102(4):1696-701.

Radak Z, Toldy A, Szabo Z, Siamilis S, Nyakas C, Silye G, et al. The effects of training and detraining on memory, neurotrophins and oxidative stress markers in rat brain. Neurochemistry international. 2006;49(4):387-92

Urso ML, Clarkson PM. Oxidative stress, exercise, and antioxidant supplementation. Toxicology. 2003;189(1):41-54.

\section{How to cite this article:}

Afzalpour ME, TaheriChadorneshin H, Abtahi-Eivary SH, AfrooziGerow E. Effect of intensive endurance training on rat brain and hepatic 8-oxoguanine DNA glycosylase and 8-hydroxy-2'deoxyguanosine levels. J App Pharm Sci, 2016; 6 (12): 110-113. 